\title{
Analysis of Mathematical Concept Understanding Capabilities: The Impact of Makerspae STEM Learning Approach Models and Student Learning Activities
}

\author{
(1) Universitas Islam Negeri Raden Intan Lampung, Indonesia \\ (2) University of Szeged, Hungary \\ (3) Universitas Islam Negeri Raden Intan Lampung, Indonesia \\ *Correspondence to: komarudin@radenintan.ac.id
}

Komarudin Komarudin $^{(1)}$, Suherman Suherman ${ }^{(2)}$, Anita Anggraini ${ }^{(3)}$

\begin{abstract}
This research aims to determine the influence of students' learning activities on the ability to understanding mathematical concepts through the STEM Learning Approach Makerspace model based on PBL on SPLDV materials. As for the type of research Quasi-Experiments. The population in this study was 90 students who were distributed into 3 classes with 2 classes that sampled grades VIII A and VIII C. The sampling techniques in this study used randomized classes and data collection techniques in this study were tests and observations, while the research instruments used preliminary tests and final tests to measure the ability to understand mathematical concepts and observation sheets to see students' learning activities. Data analysis techniques using a two-way ANOVA test. The research showed that there is an influence of the PBL-based Makerspace STEM Learning Approach model on the ability to understand mathematical concepts, there is no influence on students' learning activities on mathematical concept comprehension capabilities, and there is no interaction between the PBL-based Stem Learning Approach Makerspace model and student learning activities on the ability to understand mathematical concepts. Conclusion, there is a positive direct effect of cognitive structures on the ability to understanding mathematical concepts.
\end{abstract}

Keywords: science, technology, engineering, and mathematics; STEM learning approach makerspace; problem based learning; mathematical concepts understanding; learning activities

Recommended citation: Komarudin, K., Suherman, S., \& Anggraini, A. (2021). Analysis of Mathematical Concept Understanding Capabilities: The Impact of Makerspae STEM Learning Approach Models and Student Learning Activities. Journal of Innovation in Educational and Cultural Research, 2(1), 35-43.

\section{INTRODUCTION}

In this century, educational institutions such as schools and higher education must be able to score a superior generation (Anggraheni \& Astuti, 2020; Ekawati et al., 2019; Nurochmah et al., 2019). From this, one of the emphasized in the education system that must run in Indonesia is the learning process of students in the class (Nurdyansyah, 2018) and the purpose of mathematics learning is that students have the ability to understand the concepts (Fitrah, 2017; Komarudin et al., 2020; Mawaddah \& Maryanti, 2016a). It is mean that, the mathematics learning is a universal knowledge that is useful for $21^{\text {st }}$ century.

The ability to mathematical concepts understanding is a proficiency or mathematical proficiency that is expected to be achieved such as by showing an understanding of the mathematical concepts he studied, explain the interconnectedness between concepts and apply concepts or algorithms flexibility, accurately, efficiently, and precisely in problem solving (Mawaddah \& Maryanti, 2016b). So that, understanding mathematics concept it could be addressed by student to be proficiency.

As part of the reform efforts, the Ministry of Education and Culture has taken the initiative to improve the competence of teachers and students in the fields of Science, Technology, Engineering, and Mathematics (STEM) as well as create a learning experience that prepares students for the challenges of the $21^{\text {st }}$ century (Wijaya et al., 2016; Zubaidah, 2019). STEM is able to create a cohesive learning system and active learning because of the four aspects contained in it (Agnezi et al., 2019; Suherman et al., 2018; Sukmana, 2018; Sumarni et al., 2019). Therefore, in the implementation of learning determined student to achieved in the STEM.

Research on STEM has been widely conducted including the implementation of STEM integrated based learning projects to improve science literacy reviewed from gender (Afriana et al., 2016), influence of STEM integrated problem based learning on students' critical thinking skills (Ariyatun \& Octavianelis, 2020), application of STEM-based learning projects to understanding mathematical concepts reviewed from students' 
cognitive styles (Hariyanto et al., 2019), to mastery of concepts (Khotimah et al., 2020), to student problem solving skills (Kaniawati \& Suwarma, 2015), to improve understanding of concepts (Heryanti, 2020), cognitive ability and creative thinking (Sumarni et al., 2019), towards understanding concepts, critical thinking and creative thinking (Tipani et al., 2019). The update of this study is to use PBL-based STEM to understand the concepts seen from students' learning activities.

STEM teaches students to not only memorize concepts, but to better understand and understand the concepts of science and their relationship to technology, engineering, and mathematics in finding solutions to problems in real life (Dwijananti \& Yulianti, 2010; Yanni, 2018), so STEM can help students improve their conceptual understanding skills. The concept understanding indicator can be seen in Figure 1 (Suharto \& Widada, 2019).

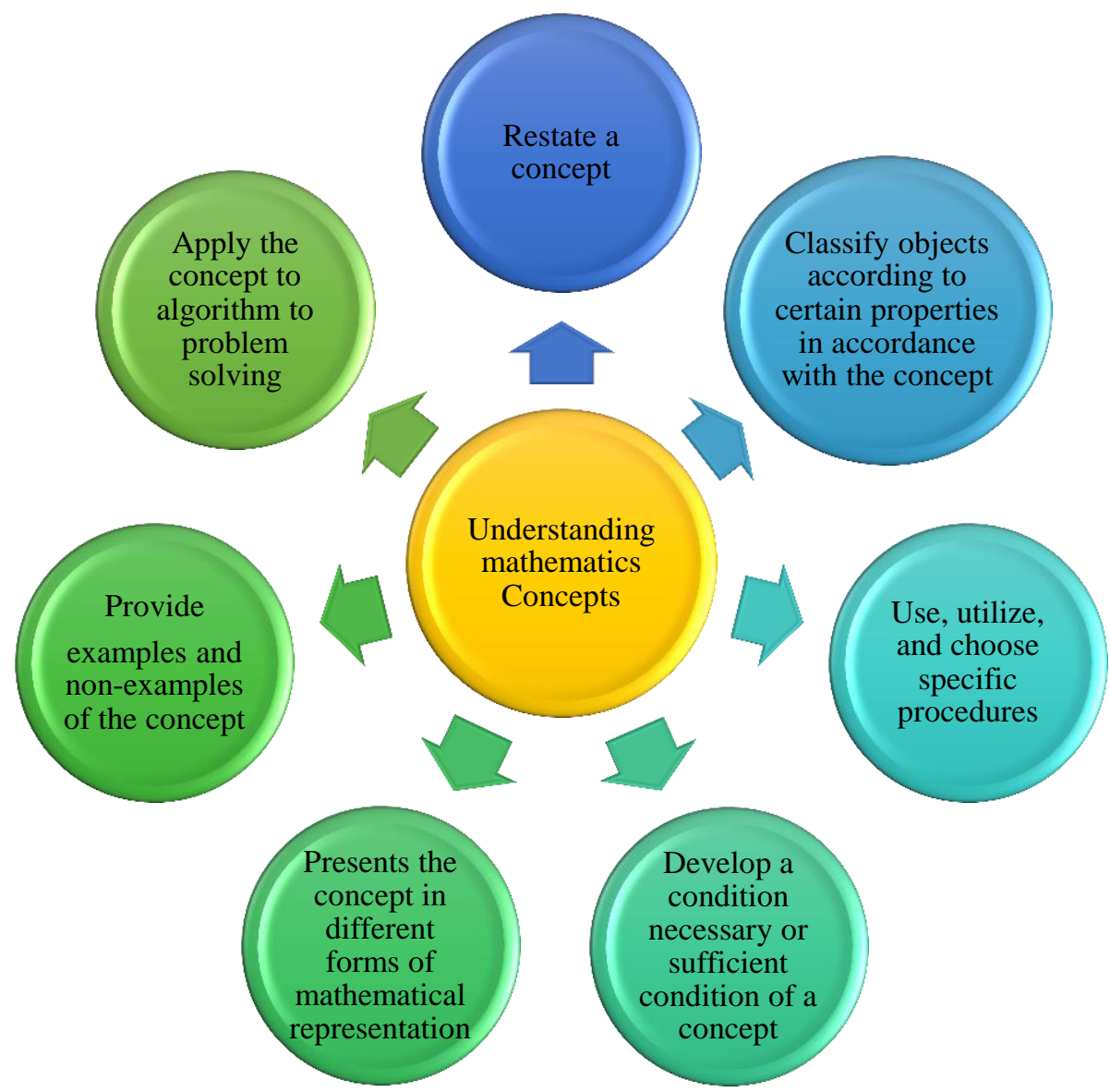

Figure 1. Indicators of Mathematical Concept Comprehension Capability

The use of approaches, learning methods and learning orientation can make learning activities in each student's classroom different. Differences in students' learning activities lead to activity levels from low learning activities to high learning activities (Widayanti, 2013). Students' learning activities will not succeed if they are not supported by improved teacher teaching activities (Yulianto et al., 2014). In the PBL-based Makerspace STEM Approach learning, teacher activities and student learning activities inside can be seen in Figure 2. 


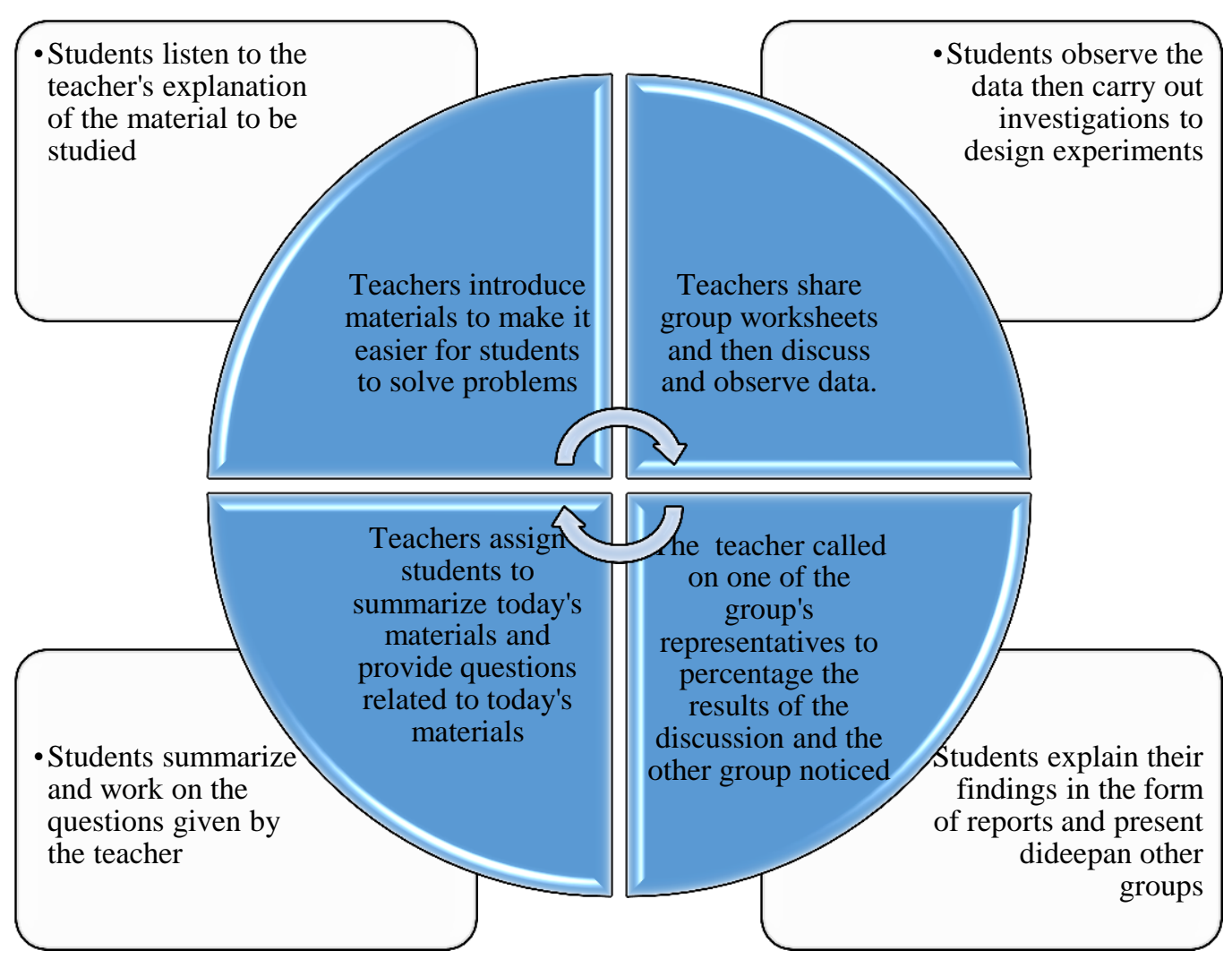

Figure 2. Storyboard of classroom activities of teachers and students

\section{METHOD}

This study was quasi-experiment design method with two-way ANOVA. These research design using two group subject from the population including two experimental classes conduct to the PBL based STEM learning approach Makerspace. Then, the control classes using PBL learning. These method is implemented to see the understanding mathematical concept. This is consistent as stated by Abrahamson, that the experimental method can be said as a research method used to the bringing mathematical concept and effect on others under controlled conditions (Abrahamson \& Trninic, 2015).

\section{Participants}

The participants of this study was all grade $8^{\text {th }}$ students in the Islamic Junior High School (MTs) Riyadlatul Ulum, Bandar Lampung, Indonesia. The number of the participant was 90 students divided into 3 classes. The samples in this study was grades $8^{\text {th }}$ in class A and class C. Sampling techniques were random sampling. The variables in this study consist of free variables namely PBL-based STEM Learning Approach Makerspace and learning activities while the bound variables were the ability to understand mathematical concepts.

\section{Instrument}

The instrument in this study was test. The test to knowing of understanding mathematical concept. Thesetest is essay with the indicators of mathematical concept and distributed by all samples classes in the experiment class and control class.

\section{Data Collection}

The data collection used is with test techniques and observation sheets. The research design used in this study can be seen in Figure 3. 


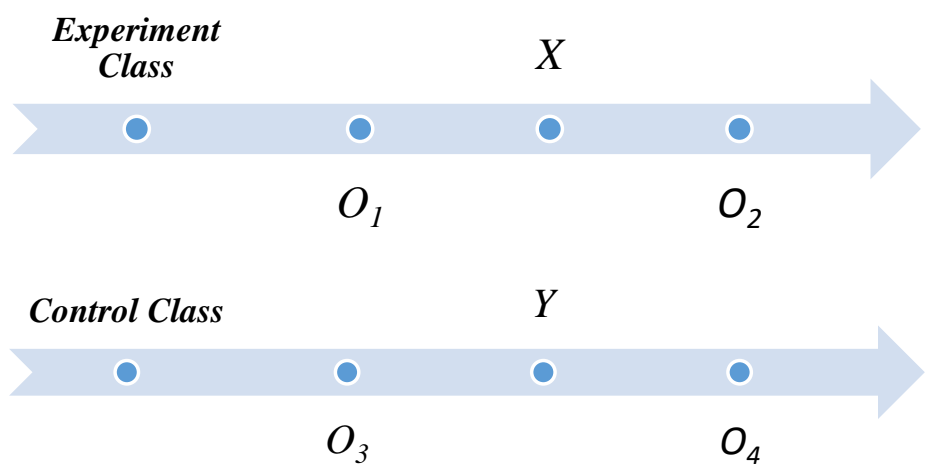

Figure 3. Research Design

Based on the Figure $3, \mathrm{O}_{1}$ is experiment class group pre-test, $\mathrm{O}_{2}$ is experiment class group post-test, $\mathrm{O}_{3}$ is pre-test control class group, $\mathrm{O}_{4}$ is post-test control class group, $\mathrm{X}$ is treatment of researchers with PBLbased STEM Learning Approach Makerspace, and $\mathrm{Y}$ is treatment of researchers using conventional learning models.

\section{Data Analysis}

The data analysis technique used is two-way ANOVA. The $n$-gain test is used to see an increase in the pre-test value to the post-test value.

\section{RESULTS AND DISCUSSIONS}

This research was conducted at MTs Riyadlatul Ulum Lampung Timur. Instruments need to be tested outside the sample class. About instruments understanding mathematical concepts as many as 14 questions to be tested. Once tested get results only 7 valid and usable questions. For reliability test about reliable interpretasi.

After the validity test, the level of difficulty, power difference and reliability then 7 tester questions can be used in the sample class. Before learning is given in the sample class is taken a pre-test value first.

The results of the pre-test grades in the experiment class and the control class can be seen in Figure 4 and the post-test values in the experiment class and the control class can be seen in Figure 5.

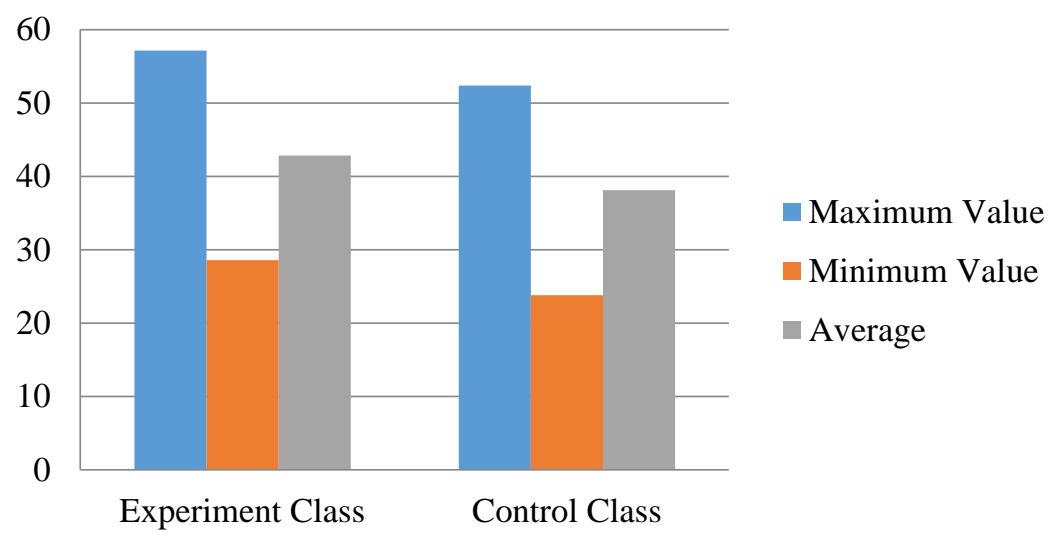

Figure 4. Experiment Class and Control Class Pre-Test Values 


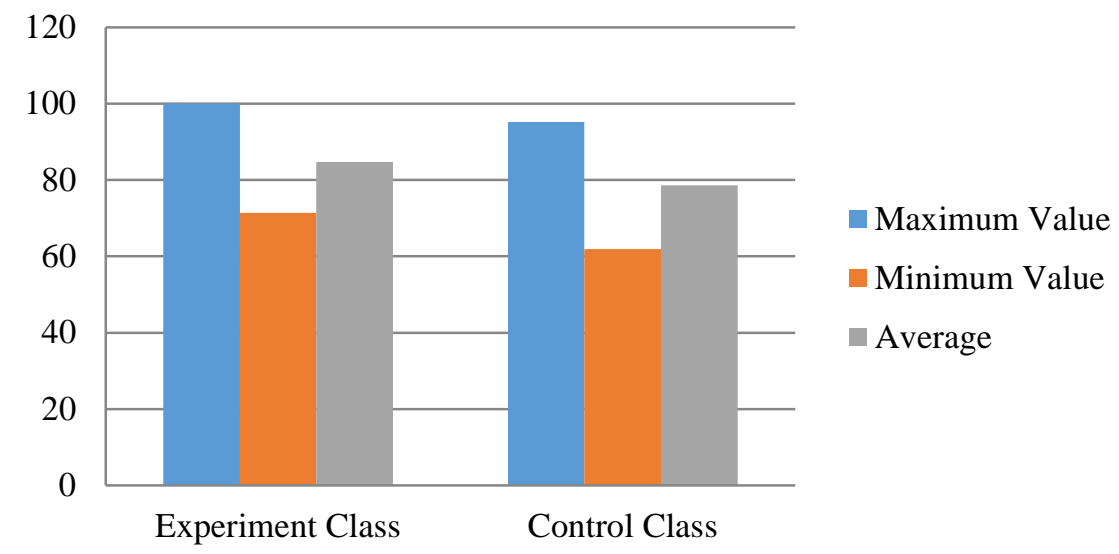

Figure 5. Post-test values of the experiment class and the control class

After taking pre-test and post-test grades in the sample class, the $\mathrm{N}$-gain or increase of each class was for the experiment class from 0.50 to 1.00 with moderate to high in achievement, while for the control class from 0.306 to 0.94 with moderate to high in achievement. This means that experiment classes after being treated with the PBL-based Makerspace STEM Learning Approach learning model for improved concept understanding capabilities. The improvement can be seen in Figure 6 .

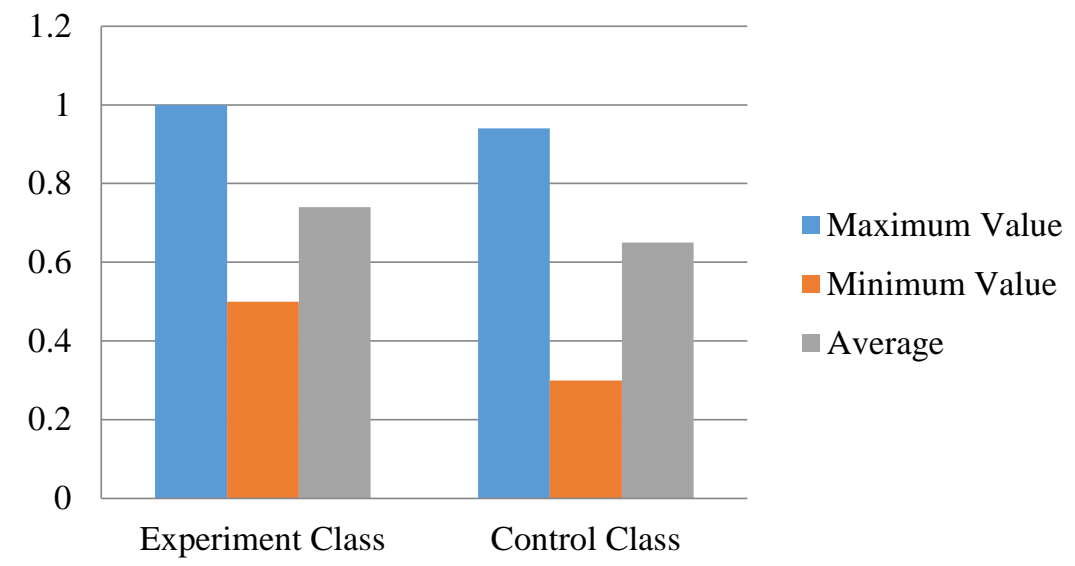

Figure 6. Experiment class $\mathrm{N}$-gain values and control classes

The observation sheet is carried out by the teacher during the learning process or assistance from another observer. In this study, the observation sheet was filled by researchers who observed the student's activities during the learning process. Observations in this study were conducted during the study. The observation sheet assessment results can be seen in Figure 7.

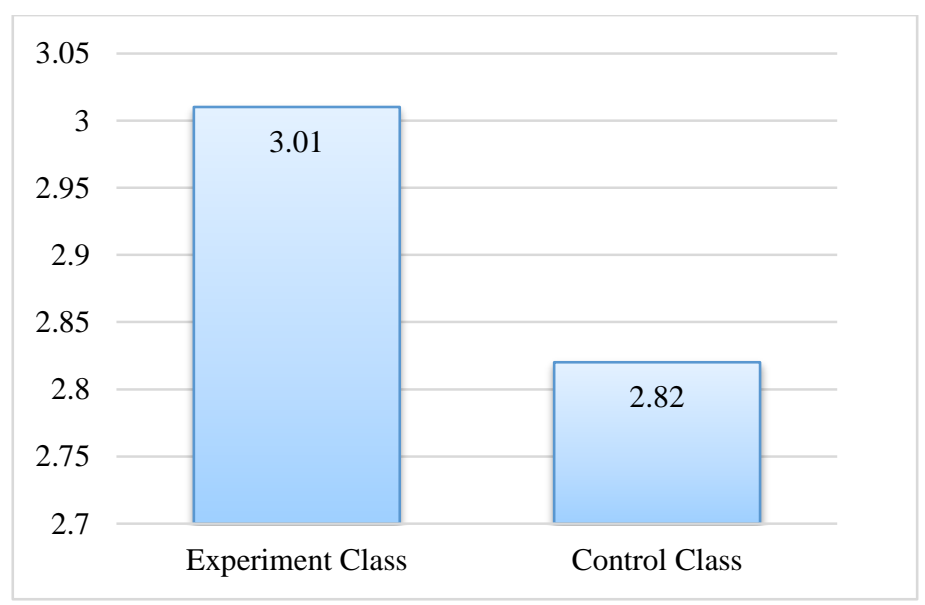

Figure 7. Average Observation Data 
Figure 7 shows that the average grade in the control class is smaller than the average score of the experiment class. From that data, it is known that experimental class students are more active with control classes. The N-gain normality test was conducted to see if the data in the study distributed nomal or not and in the research the data used should be distributed normally to further the next calculation. Test the normality of $\mathrm{n}$-gain in Table 2 .

Table 2. N-gain normality

\begin{tabular}{cccccc}
\hline \multicolumn{5}{c}{ Kolmogorov-Smirnov ${ }^{\text {a }}$} & Shapiro-Wilk \\
Class & Statistic & df & Sig. & Statisticdf Sig. \\
\hline N-GainClass Experiments & .114 & 30 & $.200^{*}$ & .948 & 30.145 \\
Class Control & .107 & 30 & $.200^{*}$ & .973 & 30.617 \\
\hline
\end{tabular}

The Table 2 shows that the sig value. The $\mathrm{N}$-gain sample class is more than the sig value. table i.e. 0.05. From the test results of normality $\mathrm{N}$-gain $L_{\text {Count }}>L_{\text {Table }}$, then the experiment class data and control class are distributed normally. The n-gain homogeneity test is used after it is known that the data is distributed normally and then continues the homogeneity test calculation to see if the data is homogeneous or not in this study can be seen in Table 3.

Table 3. Experimental Class and Control Class N-gain Homogeneity Test Results

\begin{tabular}{ccccc} 
& Levene Statistic & df1 & df2 & Sig. \\
\hline N-Gain & .145 & 1 & 58 & .705 \\
\hline
\end{tabular}

Based on the Table 3 the significant level value of mathematical concept understanding capability is 0.705 meaning significant level value $\geq 0.05$ means both samples are homogeneous. Further hypothetical tests were conducted using two-way anova, with the results can be seen in Table 4.

Table 4. Anava's Calculation of Two 10 Cell Roads Is Not the Same

\begin{tabular}{cccccr}
\hline Source & Type III Sum of Squares df Mean Square & $\mathrm{F}$ & Sig. \\
\hline Corrected Model & $2703.286^{\mathrm{a}}$ & 5 & 540.657 & 5.340 & .000 \\
Intercept & 282152.516 & 1 & 282152.516 & 2786.640 .000 \\
Activities_Learning & 143.192 & 2 & 71.596 & .707 & .498 \\
Kelas & 2511.305 & 1 & 2511.305 & 24.803 & .000 \\
Activities_Learning* Class & 371.226 & 2 & 185.613 & 1.833 & .170 \\
Error & 5467.602 & 54 & 101.252 & & \\
Total & 323399.455 & 60 & & & \\
Corrected Total & 8170.888 & 59 & & & \\
\hline
\end{tabular}

Based on the calculation of two-way anava are not the same obtained that:

1. The $F_{\text {A.Count }}=0.000$ and $F_{\text {A.table }}=0.05$. Thus $F_{\text {A.Count }} \leq F_{\text {A.Table, }}$ it can be concluded that the rejected H_OA means that there is an influence of the PBL-based Makerspace STEM Learning Approach model on understanding mathematical concepts.

2. $F_{B . \text { Count }}=0,498$ with $F_{B . \text { table }}=0,05$, this means $F_{B \text {.Count }}>F_{B . \text { Table, }}$ so $H_{0 B}$ means that there is no influence of students' learning activities on the ability to understand students' mathematical concepts

3. $\quad F_{A B \text {.count }}=0,170$ and $F_{A B \text {.table }}=0,05$. So $F_{A B \text {.Count }}>F_{A B \text {.table }}$. It can be interpreted that $H_{0 A B}$ is accepted so that there is no interaction between the use of the PBL-based Makerspace STEM Learning Approach model and student learning activities towards understanding students' mathematical concepts.

The results showed that classes implemented by PBL-based STEM Learning Approach Makerspace were better than those that conventional learning models applied to students' mathematical concept comprehension skills. Makerspace's PBL-based STEM Learning Approach model is implemented in a cool and creative atmosphere (Thahir et al., 2020). In learning that implements STEM is very profitable because it involves students (Chalim et al., 2019; Ulfa et al., 2019) and students are required to discuss giving ideas to answer questions that are in the student worksheet. It is important that PBL-based STEM learning approach can effet of the cognitive style and determine of the mathematical concept.

In the class control used a conventional learning model in which the learning centered on the teacher while the students simply listened, noted, asked about the material submitted by the teacher (Rachmawati, 
2016; Roza, 2018). This results in students being less active in the learning process as well as difficulty understanding the material that has been submitted. Unlike learning using PBL-based STEM Learning Approach Makerspace, students tend to be active. Susanti et al. (2018) says that STEM learning with practicum is an interesting innovation and can improve student learning outcomes. The achievement of the results of the results can improve by teaching and learning were used learning approach.

Therefore, students' mathematical concept understanding skills will be better if the learning process is implemented by implementing the PBL-based STEM Learning Approach Makerspace learning model compared to conventional learning models. There are similarities with previous research conducted by Farwati et al. (2018), et al who stated that the integration of PBL in STEM conveys material by discussing so that it exchanges thoughts between her group friends. As an increasing students' understanding mathematical concept abilities in PBL in STEM refers to the grouping stage of students who are followed up by the treatment given by the teachers'.

Furthermore, for student learning activities in the class obtained that does not affect the ability to understand the mathematical concepts of students but rather more related to the learning model used by the teacher. This is in line with research conducted by Sudarman \& Vahlia (2016) entitled effectiveness of the use of Quantum Learning methods towards the ability to understand the mathematical concepts of students getting results that the lack of understanding of thematic conception of students can be due to the lack of focus of students when learning due to the learning model used by teachers less attractive learning students.

Based on the results of the study, there is no interaction between the use of the PBL-based STEM Learning Approach Makerspace model and students' learning activities towards understanding students' mathematical concepts. It is likely that this is due to several factors that result in unfulfilled students focusing on the learning process and classes that are not conducive so as to disrupt the concentration of students. This mean that, the teaching and learning using PBL-based STEM learning approach can effect of the cognitive aspect, understanding mathematical concept especially.

\section{CONCLUSIONS}

The conclusions of this study with the title STEM Learning Approach Makerspace based on PBL to improve the ability to understand mathematical concepts reviewed from student learning activities are there is an influence of the PBL-based STEM Learning Approach Makerspace model on students' mathematical concept understanding capabilities., There is no influence of student learning activities on the ability to understand students' mathematical concepts, and there is no interaction between the use of the PBL-based Makerspace STEM Learning Approach model and student learning activities towards understanding students' mathematical concepts. Based on some of the things that have been conveyed before. Authors can provide suggestions such as math learning is recommended using the PBL-based Makerspace STEM Learning Approach model because students participate in the learning process. Teachers must constantly improve the ability to understand students' mathematical concepts. Students are expected to always be active in the classroom in order to further improve the ability to understand mathematical concepts.

\section{REFERENCES}

Abrahamson, D., \& Trninic, D. (2015). Bringing forth mathematical concepts: Signifying sensorimotor enactment in fields of promoted action. ZDM, 47(2), 295-306.

Afriana, J., Permanasari, A., \& Fitriani, A. (2016). Penerapan project based learning terintegrasi STEM untuk meningkatkan literasi sains siswa ditinjau dari gender. Jurnal Inovasi Pendidikan IPA, 2(2), 202212.

Agnezi, L. A., Khair, N., \& Yolanda, S. (2019). Analisis Sajian Buku Ajar Fisika SMA Kelas X Semester 1 Terkait Komponen Science, Technology, Engineering, Mathematics (STEM). Jurnal Eksakta Pendidikan (Jep), 3(2), 167-175.

Anggraheni, R., \& Astuti, R. D. (2020). Revitalisasi Nilai-Nilai Islami dalam Edukasi guna Mempersiapkan Generasi Menuju Era Society 5.0 sebagai Bagian dari Strategi Rekonstruksi Kejayaan Peradaban Islam. Prosiding Konferensi Integrasi Interkoneksi Islam Dan Sains, 2, 31-34.

Ariyatun, A., \& Octavianelis, D. F. (2020). Pengaruh Model Problem Based Learning Terintegrasi STEM terhadap Kemampuan Berpikir Kritis Siswa. Journal of Educational Chemistry (JEC), 2(1), 33-39. 
Chalim, M. N., Mariani, S., \& Wijayanti, K. (2019, February). Kemampuan Komunikasi Matematis Siswa SMK Ditinjau dari Self Efficacy pada Setting Pembelajaran Project Based Learning Terintegrasi STEM. In PRISMA, Prosiding Seminar Nasional Matematika (Vol. 2, pp. 540-550).

Dwijananti, P., \& Yulianti, D. (2010). Pengembangan kemampuan berpikir kritis mahasiswa melalui pembelajaran problem based instruction pada mata kuliah fisika lingkungan. Jurnal Pendidikan Fisika Indonesia, 6(2).

Ekawati, T., Anggoro, B. S., \& Komarudin, K. (2019). Pengembangan Modul Pembelajaran Matematika Pada Materi Statistika Terintegrasi Nilai-Nilai Keislaman. AKSIOMA: Jurnal Program Studi Pendidikan Matematika, 8(1), 184-192.

Farwati, R., Permanasari, A., Firman, H., \& Suhery, T. (2018). Integrasi Problem Based Learning dalam STEM education berorientasi pada aktualisasi literasi lingkungan dan kreativitas. Seminar Nasional Pendidikan IPA, 1(1), 198-206.

Fitrah, M. (2017). Pembelajaran berbasis masalah untuk meningkatkan pemahaman konsep matematika pada materi segiempat siswa smp. Kalamatika: Jurnal Pendidikan Matematika, 2(1), 51-70.

Hariyanto, H., Yamtinah, S., Sukarmin, S., Saputro, S., \& Mahardiani, L. (2019). Penerapan model project based learning $(\mathrm{PjBL})$ terintergrasi pendekatan STEM dalam meningkatkan pemahamahan konsep peserta didik di salah satu sekolah daerah Tangerang Selatan. In Prosiding SNPS (Seminar Nasional Pendidikan Sains) (pp. 256-261).

Heryanti, A. D. (2020). Pembelajaran berbasis STEM untuk Meningkatkan Pemahaman Konsep Energi dan Keterampilan Berpikir Kreatif melalui Projek PLTMH. Jurnal Wahana Pendidikan, 7(1), 77-84.

Kaniawati, D. S., \& Suwarma, I. K. I. R. (2015). Study literasi pengaruh pengintegrasian pendekatan stem dalam Learning Cycle $5 \mathrm{E}$ terhadap kemampuan pemecahan masalah siswa pada pembelajaran fisika. In Seminar Nasional Fisika (SiNaFi) (pp. 39-48).

Khotimah, K., Supriana, E., \& Parno, P. (2020). Pengaruh Inkuiri Terbimbing Berbasis Science, Technology, Engineering, Math (STEM) terhadap Penguasaan Konsep Siswa SMA pada Materi Fluida Statis. Jurnal Pendidikan: Teori, Penelitian, Dan Pengembangan, 5(7), 896-901.

Komarudin, K., Farida, F., Pranata, D., Nurhasanah, U., \& Suherman, S. (2020). Developing Islamic-Friendly Android Mobile Apps for Understanding Mathematical Concepts. 1st Raden Intan International Conference on Muslim Societies and Social Sciences (RIICMUSSS 2019), 110-117.

Mawaddah, S., \& Maryanti, R. (2016a). Kemampuan pemahaman konsep matematis siswa SMP dalam pembelajaran menggunakan model penemuan terbimbing (discovery learning). Edu-Mat: Jurnal Pendidikan Matematika, 4(1).

Mawaddah, S., \& Maryanti, R. (2016b). Kemampuan Pemahaman Konsep Matematis Siswa SMP dalam Pembelajaran Menggunakan Model Penemuan Terbimbing (Discovery Learning). EDU-MAT, 4(1).

Nurdyansyah, N. (2018). Model Pembelajaran Berbasis Masalah Pada Pelajaran IPA Materi Komponen Ekosistem. Universitas Muhammadiyah Sidoarjo.

Nurochmah, A., Sutisnawati, A., \& Wardana, A. E. (2019). Pengelolaan Satuan Pendidikan dalam Rangka Mencetak Insan Generasi Muda yang Unggul di Sekolah Dasar. Jurnal Holistika, 3(2), 73-80.

Rachmawati, W. (2016). Penggunaan Model Pembelajaran STAD untuk Meningkatkan Hasil Belajar Siswa Materi Koperasi IPS di Sekolah Dasar. Jurnal Penelitian Pendidikan Guru Sekolah Dasar, 3(2).

Roza, M. (2018). Penerapan Model Eliciting Activities (MEAs) terhadap Kemampuan Komunikasi Matematis Siswa Kelas XI. Jurnal Kepemimpinan Dan Pengurusan Sekolah, 3(2), 119-128.

Sudarman, S. W., \& Vahlia, I. (2016). Efektifitas Penggunaan Metode Pembelajaran Quantum Learning terhadap Kemampuan Pemahaman Konsep Matematis Mahasiswa. Al-Jabar: Jurnal Pendidikan Matematika, 7(2), 275-282.

Suharto, S., \& Widada, W. (2019, April). The Cognitive Structure of Students in Understanding Mathematical Concepts. In International Conference on Educational Sciences and Teacher Profession (ICETeP 2018) (pp. 65-69). Atlantis Press.

Suherman, S., Komarudin, K., Rosyid, A., Aryanita, S., Asriyanto, D., Aradika Putra, T., \& Anggoro, T. (2018, September). Improving Trigonometry Concept Through STEM (Science, Technology, Engineering, and Mathematics) Learning. In International Conference On Multidisciplinary Academic (ICMA). 
Sukmana, R. W. (2018). Pendekatan Science, Technology, Engineering and Mathematics (STEM) Sebagai Alternatif dalam Mengembangkan Minat Belajar Peserta Didik Sekolah Dasar. Pendas: Jurnal Ilmiah Pendidikan Dasar, 2(2), 189-197.

Sumarni, W., Wijayati, N., \& Supanti, S. (2019). Kemampuan kognitif dan berpikir kreatif siswa melalui pembelajaran berbasis proyek berpendekatan STEM. Jurnal Pembelajaran Kimia OJS, 4(1), 18-30.

Susanti, L. Y., Hasanah, R., \& Khirzin, M. H. (2018). Penerapan Media Pembelajaran Kimia Berbasis Science, Technology, Engineering, and Mathematics (STEM) untuk Meningkatkan Hasil Belajar Siswa SMK/SMA pada Materi Reaksi Redoks. Jurnal Pendidikan Sains (JPS), 6(2), 32-40.

Thahir, A., Anwar, C., Saregar, A., Choiriah, L., Susanti, F., \& Pricilia, A. (2020). The Effectiveness of STEM Learning: Scientific Attitudes and Students' Conceptual Understanding. Journal of Physics: Conference Series, 1467(1), 012008.

Tipani, A., Toto, T., \& Yulisma, L. (2019). Implementasi Model Pjbl Berbasis Stem Untuk Meningkatkan Penguasaan Konsep Dan Kemampuan Berpikir Analitis Siswa. Bio Educatio:(The Journal of Science and Biology Education), 4(2).

Ulfa, F. M., Asikin, M., \& Dwidayati, N. K. (2019). Membangun Kemampuan Berpikir Kreatif Matematis Siswa dengan Pembelajaran PjBL terintegrasi Pendekatan STEM. Prosiding Seminar Nasional Pascasarjana (PROSNAMPAS), 2(1), 612-617.

Widayanti, L. (2013). Peningkatan aktivitas belajar dan hasil belajar siswa dengan metode problem based learning pada siswa kelas VIIA MTs. Jurnal Fisika Indonesia, 17(49).

Wijaya, E. Y., Sudjimat, D. A., Nyoto, A., \& Malang, U. N. (2016). Transformasi pendidikan abad 21 sebagai tuntutan pengembangan sumber daya manusia di era global. Prosiding Seminar Nasional Pendidikan Matematika, 1(26), 263-278.

Yanni, M. H. (2018). Meningkatkan Aktivitas dan Hasil Belajar Matematika Melalui Strategi Pembelajaran TAPPS Berbasis Pendekatan (STEM). Jurnal Pendidikan Matematika: Judika Education, 1(2), 117-125.

Yulianto, W. D., Sumardi, K., \& Berman, E. T. (2014). Model Pembelajaran Teams Games Tournament Untuk Meningkatkan Hasil Belajar Siswa SMK. Journal of Mechanical Engineering Education, 1(2), 323330.

Zubaidah, A. (2019). Pengembangan perangkat pembelajaran berbasis modelling instruction berbantuan Science, Technology, Engineering and Mathematics (STEM) pada materi usaha dan energi untuk meningkatkan hasil belajar peserta didik. Universitas Negeri Malang. 